\title{
Characterization of IFNy-producing natural killer cells induced by cytomegalovirus reactivation after haploidentical hematopoietic stem cell transplantation
}

\author{
Fengyan Jin' ${ }^{1}$, Hai Lin ${ }^{1}$, Sujun Gao, Hengxiang Wang' ${ }^{2}$, Hongmin Yan², Jinglong \\ $\mathrm{Guo}^{3}$, Zheng $\mathrm{Hu}^{3}$, Chunhui Jin ${ }^{3}$, Yongqi Wang ${ }^{2}$, Zhidong Wang ${ }^{2}$, Yangzhi Zhao ${ }^{1}$, Yu \\ Liu $^{1}$, Xiaoli Zheng ${ }^{2}$, Yehui Tan ${ }^{1}$, Wei Li $^{1}$, Yun Dai ${ }^{1,3}$ and Yanping Yang ${ }^{1}$ \\ ${ }^{1}$ Department of Hematology, Cancer Center, the First Bethune Hospital of Jilin University, Changchun, Jilin, China \\ ${ }^{2}$ Department of Hematology, Air Force General Hospital, the Chinese People's Liberation Army, Beijing, China \\ ${ }^{3}$ Institute of Translational Medicine, the First Bethune Hospital of Jilin University, Changchun, Jilin, China \\ Correspondence to: Yun Dai, email:YUN.DAl@vcuheath.org \\ Yanping Yang, email: yangyanping_1978@163.com \\ Keywords: NK cells, NKG2C, KIR, IFNy, cytomegalovirus, Pathology Section \\ Received: April 11,2015 Accepted: December 02, $2016 \quad$ Published: December 12, 2016
}

\section{ABSTRACT}

During human cytomegalovirus (CMV) infection after umbilical cord blood or HLA-matched hematopoietic stem cell transplantation (HSCT), a population of NKG2Cexpressing natural killer (NK) cells expand and persist. The expanded NK cells express high levels of inhibitory killer immunoglobulin-like receptors (KIR) specific for selfHLA and potently produce IFNy. However, it remains unknown whether similar events would occur after haploidentical HSCT (haplo-HSCT). Here, we demonstrated that IFNy-producing NK cells were expanded in haplo-HSCT patients with CMV reactivation. We then identified these expanded cells as a subset of CD56 dim NK cells that expressed higher levels of both NKG2C and KIR, but lower level of NKG2A. Functionally, the subset of NK cells expressing NKG2C and self-KIR in patients with CMV reactivation accounted for IFNy production in response to $\mathrm{K562}$ cells. However, these phenomena were not observed in patients without $\mathrm{CMV}$ reactivation. We therefore characterized a subset of NK cells with the CD56 dim, NKG2C ${ }^{+}$, and self-KIR ${ }^{+}$phenotype that expanded and were responsible for IFNy production during CMV infection after haplo-HSCT. Together, these findings support a notion that CMV reactivation induces expansion of more mature NK cells with memory-like features, which contributes to long-term control of both CMV infection and leukemia relapse after haplo-HSCT.

\section{INTRODUCTION}

Allogeneic hematopoietic stem cell transplantation (HSCT) is a well-established and life-saving treatment for many patients with cancer, particularly hematological malignancies [1]. While it is ideal to perform HSCT using cells from an human leukocyte antigen (HLA)-matched related donor (MRD) such as HLA-identical sibling, about two-thirds of patients would however have no MRD available for HSC donation [2]. Thus, haploidentical HSCT (haplo-HSCT), with the advantage of more choice in donor selection, offers an alternative approach for treatment of patients with advanced leukemia, particularly those who have neither MRD and HLA-matched unrelated donor (MUD), nor umbilical cord blood available for transplantation [2].

NK cells, as the first population of lymphocytes that reconstitute in recipients after HSCT, play a pivotal role in defense against infections and leukemia relapse, two major challenges for success of haplo-HSCT. The function of NK cells is regulated by diverse surface receptors that transmit either activating or inhibitory signals into NK cells [3-5]. Accordingly, the surface receptors on NK cells include the activating and inhibitory forms of the C-type lectin-like family receptors (NKG2s) and the killer cell immunoglobulin (Ig)-like receptors (KIRs). In normal individuals, both activating and inhibitory receptors on 
Table 1: Clinical characteristics of haplo-HSCT patients $(n=29)$

\begin{tabular}{ll}
\hline Characteristics & Number of patients (n) \\
\hline Age, median (range) & 24 yrs $(5-45)$ \\
\hline Gender & 17 \\
\hline Male & 12 \\
\hline Female & \\
\hline Disease type & 12 \\
\hline Acute myeloid leukemia & 14 \\
\hline Acute lymphoblastic leukemia & 3 \\
\hline Other hematologic malignancy & 14 \\
\hline Risk stratification & 15 \\
\hline Intermediate & 19 \\
\hline high & 12 \\
\hline Time of transplantation & 17 \\
\hline CR1 & 36 days (19 - 69) \\
\hline CR2 & \\
\hline Time after HSCT, median (range) & 10 \\
\hline CMV reactivation & \\
\hline Yes & \\
\hline No & \\
\hline
\end{tabular}

$\mathrm{CR}$, complete remission

NK cells are involved in killing of virus-infected cells or tumor cells via the corresponding signals triggered by binding of the specific their cognate ligands, class I HLA molecules [6]. After binding to the specific ligands on target cells, while the inhibitory receptors prevent the cytotoxic action of NK cells, stimulation of the activating receptors mediates killing of target cells by NK cells [7]. Of note, whereas primary human CMV infection usually occurs asymptomatically, virus infection could be a potentially life-threatening complication in patients with immunodeficiency, e.g., transplantation recipients [8]. Responses to cytomegalovirus (CMV) infection lead to stable imprints in the KIR repertoire of human NK cells [9]. Moreover, latent CMV infection induces a permanent up-regulation of the activating receptor NKG2C [10, 11], in association with modulation of the NK cell KIR repertoire $[12,13]$. Recently, increasing evidence indicates that NK cells also exhibit memory-like properties comparable to B and T lymphocytes $[14,15]$.

Following CMV reactivation in patients who have received CMV-naive umbilical cord blood or MUD HSCT, a subset of reconstituting NK cells expand and display an increased density of surface NKG2C $[10,11]$. Interestingly, these NK cells often persist for long term (e.g., a year after transplantation) even after viral clearance, indicating their memory-like features. Moreover, they have been characterized by predominant expression of NKG2C and the inhibitory KIR specific for self-HLA, but lack of NKG2A, a phenotype required for robust IFN $\gamma$ production [10]. However, it remains unknown whether similar CMV-induced events also occur in patients after haplo-HSCT that often causes delayed immune reconstitution due to more severe immunosuppression than HLA-matched HSCT. The aim of our study was to determine and characterize NK cells that expand and function to produce IFN $\gamma$ during CMV reactivation in patients with hematologic malignancies who have received the treatment of haplo-HSCT.

\section{RESULTS}

\section{IFN $\gamma$-producing NK cells expand in response to CMV reactivation in haplo-HSCT patients}

Recent studies have demonstrated that the expansion of IFN $\gamma$-producing NK cells is specifically associated with 
Table 2: Characteristics of KIR and HLA ligands in haplo-HSCT patients $(n=29)$

\begin{tabular}{|c|c|c|c|c|c|c|c|}
\hline \multirow{2}{*}{$\begin{array}{c}\text { Patient } \\
\text { s }\end{array}$} & \multirow{2}{*}{$\begin{array}{c}\text { Donor } \\
\text { KIR }\end{array}$} & \multicolumn{4}{|c|}{ KIR-ligand genotype of patients } & \multirow{2}{*}{ Self-KIR } & \multirow{2}{*}{ CMV } \\
\hline & & HLA-C1 & HLA-C2 & HLA-Bw4 & HLA-A03/11 & & \\
\hline 1 & 2DL2 & + & - & + & - & $\mathrm{Y}$ & + \\
\hline 2 & 2DL1 & + & - & - & + & $\mathrm{N}$ & + \\
\hline 3 & 2DL3 & + & - & - & - & $\mathrm{Y}$ & + \\
\hline 4 & 3DLl & - & + & - & - & $\mathrm{N}$ & + \\
\hline 5 & 2DL1 & - & + & + & - & $\mathrm{Y}$ & + \\
\hline 6 & 2DL3 & - & + & - & - & $\mathrm{N}$ & + \\
\hline 7 & 3DL1 & - & + & + & - & $\mathrm{Y}$ & + \\
\hline 8 & 2DL2 & - & + & - & - & $\mathrm{N}$ & + \\
\hline 9 & 2DL2 & + & - & + & - & $\mathrm{Y}$ & + \\
\hline 10 & 2DL3 & + & - & - & - & $\mathrm{Y}$ & + \\
\hline 11 & 3DL1 & + & + & - & - & $\mathrm{N}$ & + \\
\hline 12 & 2DL1 & + & - & + & - & $\mathrm{N}$ & + \\
\hline 13 & 2DL2 & + & + & + & - & $\mathrm{Y}$ & + \\
\hline 14 & 3DL1 & + & + & + & - & $\mathrm{Y}$ & + \\
\hline 15 & 2DL1 & + & - & - & + & $\mathrm{N}$ & + \\
\hline 16 & 2DL3 & + & + & + & - & $\mathrm{Y}$ & + \\
\hline 17 & 2DL2 & - & + & + & - & $\mathrm{N}$ & + \\
\hline 18 & $2 \mathrm{DL} 1$ & + & - & - & - & $\mathrm{N}$ & + \\
\hline 19 & 3DL1 & + & - & + & - & $\mathrm{Y}$ & + \\
\hline 20 & $2 \mathrm{DLl}$ & - & + & - & + & $\mathrm{Y}$ & - \\
\hline 21 & 3DL1 & + & - & + & - & $\mathrm{Y}$ & - \\
\hline 22 & 3DL1 & - & + & - & - & $\mathrm{N}$ & - \\
\hline 23 & 2DL3 & + & + & - & - & $\mathrm{Y}$ & - \\
\hline 24 & 2DL2 & - & + & - & + & $\mathrm{N}$ & - \\
\hline 25 & 2DL1 & + & - & + & - & $\mathrm{N}$ & - \\
\hline 26 & 3DL1 & - & + & + & - & $\mathrm{Y}$ & - \\
\hline 27 & 2DL3 & + & - & - & - & $\mathrm{Y}$ & - \\
\hline 28 & 2DL2 & - & + & + & - & $\mathrm{N}$ & - \\
\hline 29 & $2 \mathrm{DL1}$ & + & - & - & - & $\mathrm{N}$ & - \\
\hline
\end{tabular}

CMV infection in patients after umbilical cord blood and HLA-matched allogeneic HSCT [10, 11]. We thus first examined whether similar event also occurs in patients after haplo-HSCT. As NK cell counts are significantly different between patients who had grades 2-4 acute graft-versus-host disease (GVHD) versus grades 0-1 within six months after transplantation, we examined the percentage of IFN $\gamma$-producing NK cells only in patients who had grades 0-1 GVHD after haplo-HSCT, in order to avoid such effects of GVHD. The clinical characteristics for these patients with hematologic malignancies were summarized in Table 1. CMV reactivation was monitored by qPCR twice a week in all patients. The antiviral therapy was given when CMV was detected, and CMV became undetectable in the blood after 2 to 4 week treatment. In a total of 29 patients, 19 had CMV reactivation, while 10 were CMV-seronegative. Because target cellinduced IFN $\gamma$ production of $\mathrm{NK}$ cells in recipients of unmanipulated or $\mathrm{CD} 4^{+}$selected grafts usually drops to the basal levels in normal donors after 6 months post HSCT [16], we therefore decided to carry out all of the analyses within the first 180 days after haplo-HSCT. To 
this end, peripheral blood mononuclear cells (PBMCs) were collected from each patient at day 30, 60, 90, 120, 150, and 180 after haplo-HSCT. Notably, all 19 patients with CMV reactivation displayed expansion of IFN $\gamma$ producing NK cells, in whom the percentages of IFN $\gamma$ producing NK cells were significantly increased from day 60 to 180 after transplantation, compared to those for their donors (day 60, $10.93 \pm 2.64$ versus $6.13 \pm 1.46, P=$ 0.045 ; day $90,13.42 \pm 2.26$ versus $6.13 \pm 1.46, P=0.015$; day $120,11.23 \pm 0.61$ versus $6.13 \pm 1.46, P=0.038$; day $150,11.98 \pm 2.46$ versus $6.13 \pm 1.46, P=0.025$; day 180 , $11.76 \pm 2.19$ versus $6.13 \pm 1.46, P=0.021$; Figure 1 ). This NK cell response started at day 60 , with a maximum at day 90, after transplantation. In sharp contrast, there was no increase in the percentage of IFN $\gamma$-producing NK cells in patients without CMV reactivation $(P>0.05$ for all time points, compared to those for their donors, while $P<0.05$ for comparisons between patients with or without CMV reactivation after 60 days post transplantation). These findings indicate that as previously observed in the case of umbilical cord blood or HLA-matched allogeneic HSCT, the expansion of IFN $\gamma$-producing NK cells also occurs in CMV-seropositive, but not -seronegative, patients with after haplo-HSCT.

\section{CMV reactivation induces a more mature phenotype of NK cells after haplo-HSCT}

We next phenotyped IFN $\gamma$-producing NK cells in haplo-HSCT patients with CMV reactivation. NK cell differentiation is featured by CD56 expression on cell surface. In peripheral blood of normal individuals, only approximately $2-10 \%$ NK cells display a high density of surface CD56 (designated CD56 $6^{\text {bright }}$ ), while a majority ( $90 \%$ ) of NK cells have a low density of surface CD56 (designated CD56 ${ }^{\mathrm{dim}}$ ). While the CD56 ${ }^{\mathrm{dim}}$ subset of NK cells exhibit limited potential of proliferation, they become functionally active, reflected by KIR expression and an abundance of intracellular cytotoxic granules, in response to ex vivo stimulation with interleukin-2 or interleukin-15 $[15,17-19]$. We thus analyzed the CD56 ${ }^{\mathrm{dim}}$ population of NK cells in haplo-HSCT patients with CMV infection. Although a modest increase of the CD56 ${ }^{\text {dim }}$ NK cell population was observed after day 60 post transplantation, there was no statistically significant difference in the percentages of CD56 $6^{\mathrm{dim}} \mathrm{NK}$ cells between patients with and without $\mathrm{CMV}$ reactivation at all time points $(P>$ 0.05 , Figure 2A). As expression of the C-type lectinlike receptor $\mathrm{NKG} 2 \mathrm{C}$ that recognizes HLA-E represents a major activating signal in NK cells [20], we further examined expression of $\mathrm{NKG} 2 \mathrm{C}$ on $\mathrm{CD} 56^{\mathrm{dim}} \mathrm{NK}$ cells.

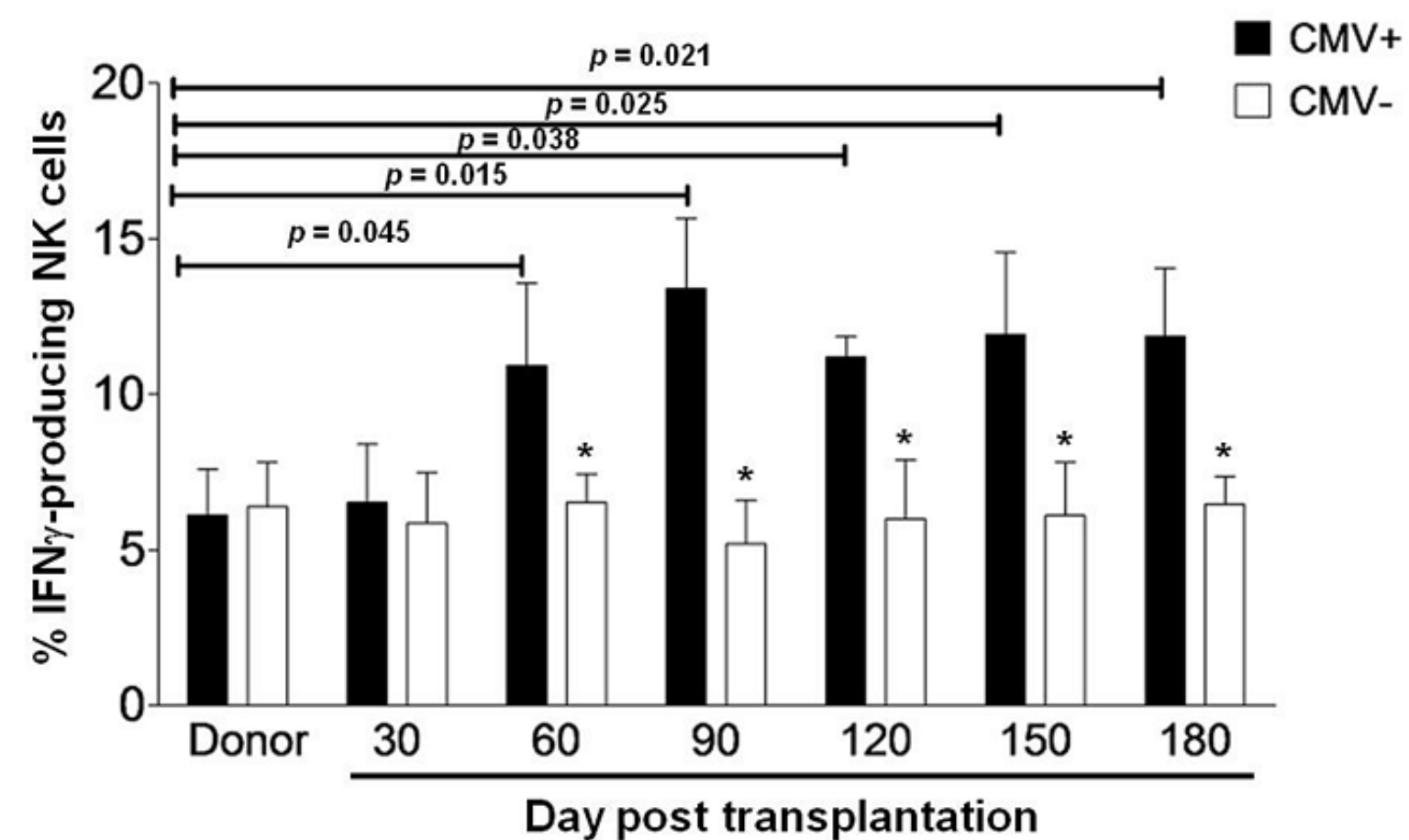

Figure 1: IFN $\gamma$-producing NK cells expand in haplo-HSCT patients with CMV reactivation. PBMCs from the donors before haplo-HSCT $(n=10)$ and the haplo-HSCT patients who had acute GVHD 0-1 after haplo-HSCT $(n=29)$ were collected and analyzed by flow cytometry at days 30,60, 90, 120,150 and 180 after transplantation. Cells were then incubated with K562 cells for 5 hrs, after which the percentage of NK cells producing IFN $\gamma$ was measured in the $\mathrm{CD} 56^{+} / \mathrm{CD}^{-}$subset. IFN $\gamma$ production was measured in 19 patients with $\mathrm{CMV}$ reactivation $\left(\mathrm{CMV}^{+}\right)$and 10 patients without $\mathrm{CMV}$ reactivation $\left(\mathrm{CMV}^{-}\right)$. Values represent mean $\pm \mathrm{SEM} . * P<0.05$ for comparisons between the $\mathrm{CMV}^{+}$and $\mathrm{CMV}^{-}$samples. 
Notably, the percentage of NKG2C-expressing NK cells in the CD56 ${ }^{\mathrm{dim}}$ subset was significantly higher in haploHSCT patients with CMV reactivation, compared to that in patients without CMV reactivation (day 60, $16.03 \pm$ 2.85 vs $12.16 \pm 2.21, P=0.042$; day $90,19.92 \pm 2.04$ vs $10.13 \pm 1.57, P=0.0068$; day $120,21.77 \pm 1.27$ vs 10.53 $\pm 2.37, P=0.0045$; day $150,20.53 \pm 2.35$ vs $9.33 \pm 2.46$, $P=0.0052$; day $180,20.65 \pm 3.22$ vs $9.06 \pm 1.07, P=$ 0.0040 ; Figure 2B). To exclude a possibility that HLA-E alterations might alter $\mathrm{NKG} 2 \mathrm{C}$ expression, another C-type lectin-like receptor $\mathrm{NKG} 2 \mathrm{~A}$, which also recognizes HLA-E but acts as an inhibitory signal in NK cells, was monitored in parallel [5]. In contrast to increased NKG2C expression, there was no significant difference in the percentage of NKG2A-expressing CD56 ${ }^{\text {dim }} \mathrm{NK}$ cells between patients with or without $\mathrm{CMV}$ reactivation, while instead, a moderate decrease was noted in patients with CMV reactivation although not statistically significant $(P$ $>0.05$ at each time point; Figure 2C).

Similar to expression of the activating receptor Ly49H in mice after CMV infection [21], KIRs are expressed on NK cells during human CMV reactivation $[10,11]$, an event required for educating NK cells to

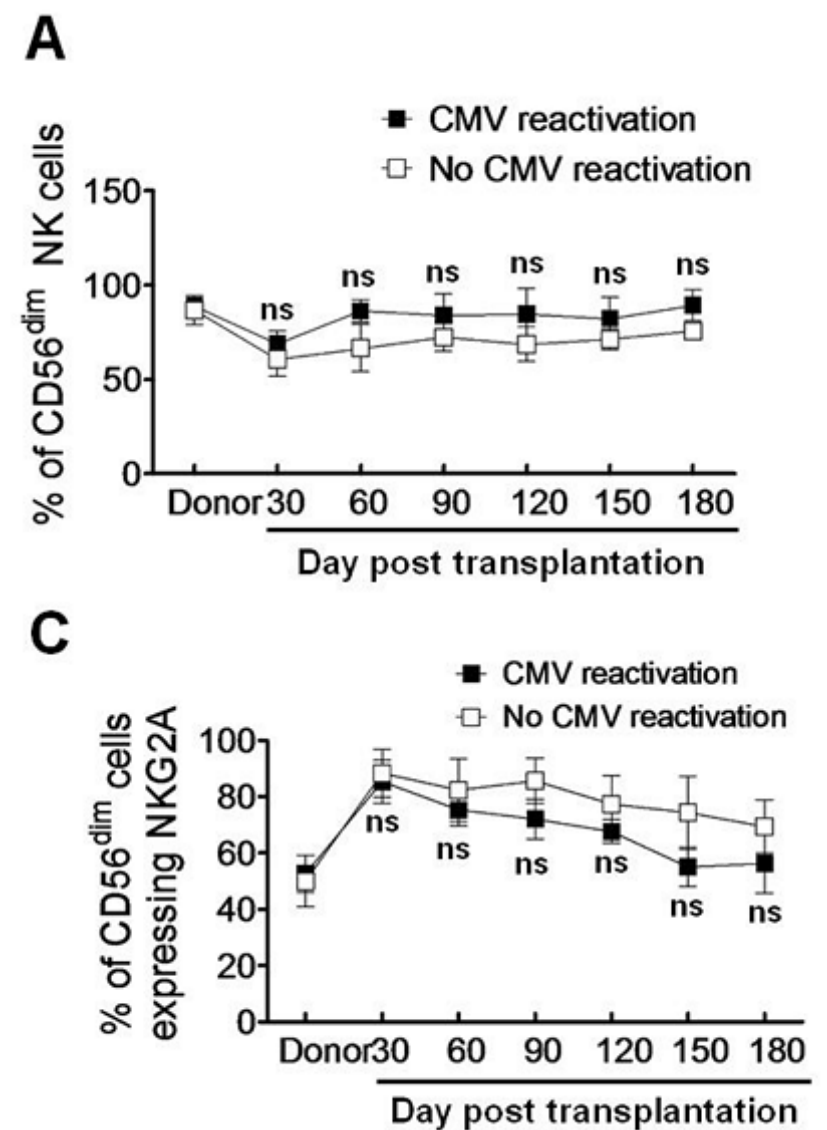

produce IFN $\gamma$ after allogeneic HSCT [22]. In this context, we then examined expression of KIRs on CD56 $6^{\mathrm{dim}} \mathrm{NK}$ cells in response to CMV infection after haplo-HSCT. Again, the percentage of KIR-expressing NK cells was significantly higher in haplo-HSCT patients with CMV reactivation than those without CMV reactivation (day 60 , $44.64 \pm 7.03$ vs $33.53 \pm 5.78, P=0.045$; day $90,47.67 \pm$ 7.51 vs $26.67 \pm 3.38, P=0.028$; day $120,57.25 \pm 5.51$ vs $31.35 \pm 5.76, P=0.015$; day $150,53.62 \pm 3.18$ vs $36.42 \pm$ 4.91, $P=0.036$; day $180,55.26 \pm 5.17$ vs $34.32 \pm 6.17, P$ $=0.030$; Figure 2D). Together, these findings suggest that $\mathrm{CMV}$ reactivation induces a more mature phenotype of NK cells featured by CD56 $6^{\mathrm{dim}}$ and expression of $\mathrm{NKG} 2 \mathrm{C}$ and KIR after haplo-HSCT.

Self-KIR is preferentially expressed on the expanded $\mathrm{NKG}^{+} \mathrm{C}^{+} \mathrm{NK}$ cells in response to $\mathrm{CMV}$ reactivation after haplo-HSCT

As KIR expression is required for educating $\mathrm{NKG}_{2} \mathrm{C}^{+} \mathrm{NK}$ cells to produce IFN $\gamma[10,11]$, we then examined whether KIRs are preferentially expressed on

B
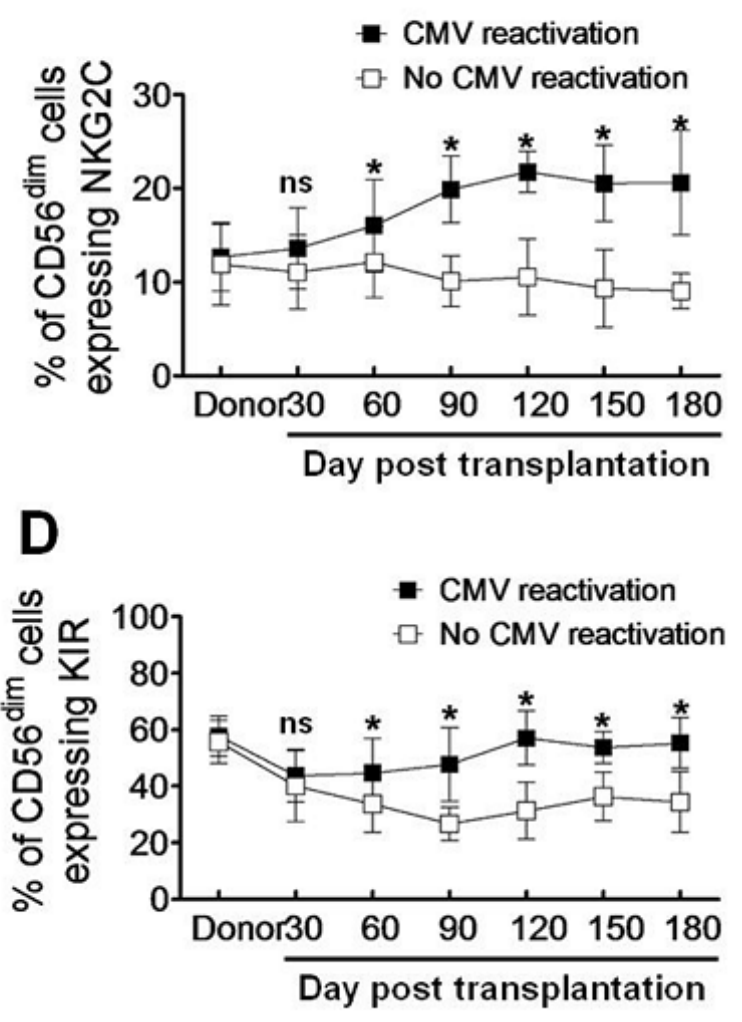

Figure 2: CMV reactivation induces a mature phenotype of NK cells $\left(C D 56^{\mathrm{dim}}\right)$ expressing NKG2C and KIR after haplo-HSCT. The percentages of CD56 ${ }^{\mathrm{dim}} \mathrm{NK}$ cells A., as well as NK cells expressing NKG2C B., NKG2A C. and KIR D. in the CD56 ${ }^{\mathrm{dim}}$ subset were determined by flow cytometry in patients with $(\square, n=19)$ without CMV reactivation $(\square, n=10)$ at days $30,60,90,120,150$, and 180 after haplo-HSCT. Values represent mean \pm SEM. $* P<0.05$ and ns (not significant) $P>0.05$ for comparisons between the CMV reactivation and no reactivation groups. 
$\mathrm{NKG}_{2} \mathrm{C}^{+} \mathrm{NK}$ cells in patients with $\mathrm{CMV}$ reactivation after haplo-HSCT. Since CD56 ${ }^{\mathrm{dim}} \mathrm{NKG} 2 \mathrm{C}^{+} \mathrm{NK}$ cells were expanded in response to CMV reactivation (Figure $2 \mathrm{~B}$ ), we selected this subset of NK cells for further analyses. There was a significant increase in the percentage of CD56 $\mathrm{dim}$ $\mathrm{NKG} 2 \mathrm{C}^{+} \mathrm{NK}$ cells expressing $\mathrm{KIR}\left(\mathrm{KIR}^{+}\right)$, compared to that for $\mathrm{KIR}^{-}$cells, in patients with $\mathrm{CMV}$ reactivation at each time point after 60 days post transplantation (day 60 , $14.06 \pm 2.47$ vs $7.81 \pm 0.76, P=0.046$; day $90,16.34 \pm$ 2.02 vs $9.03 \pm 1.15, P=0.037$; day $120,20.25 \pm 2.08 v s$ $10.56 \pm 1.43, P=0.032$; day $150,16.67 \pm 3.38$ vs 10.63 $\pm 2.25, P=0.043$; day $180,26.67 \pm 2.84$ vs $13.56 \pm 1.93$, $P=0.022$; Figure 3A). However, such a phenomenon was not observed in haplo-HSCT patients without CMV reactivation $(P>0.05$ for each time point; Figure $3 \mathrm{~B})$.

KIRs specifically recognize the HLA class I ligands that contain four polymorphic epitopes for HLA-A, -B, and $-\mathrm{C}$ each. $\mathrm{C} 1$ and $\mathrm{C} 2$ epitopes of HLA are distinguished from each other by different amino acids at position 80 [23]. C1 epitope recognizes the inhibitory receptors
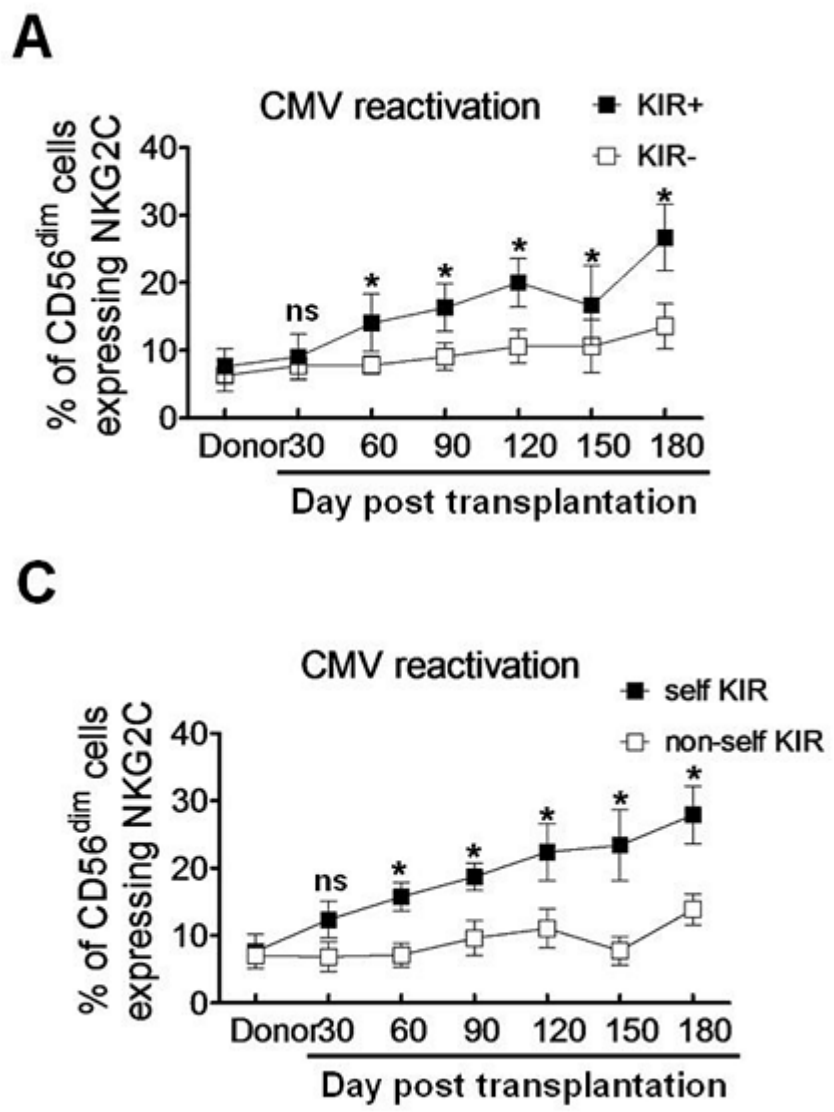

KIR2DL2/3, while C2 recognizes both the inhibitory receptor KIR2DL1 and the activating receptor KIR2DS1. Bw4 and A3/11 epitope of HLA also recognize KIR3DL1 and KIR3DL2, respectively [24-26]. The inhibitory KIR specific for self-MHC I is known as self-KIR, while that not specific for self-MHC I as non-self KIR. The characteristics of KIR and HLA ligands in donors and haplo-HSCT patients were shown in Table 2. Because expanded $\mathrm{NKG} 2 \mathrm{C}^{+} \mathrm{NK}$ cells might be educated through self-HLA class-I, we next examined whether individual KIR that recognizes self-HLA would be preferentially expressed. In 19 patients with CMV reactivation, 10 patients had self-KIR ${ }^{+} \mathrm{NK}$ cells, while 9 patients had non-self $\mathrm{KIR}^{+} \mathrm{NK}$ cells. The percentage of self-KIR ${ }^{+} \mathrm{NK}$ cells in the $\mathrm{CD}^{2} 6^{\mathrm{dim}} \mathrm{NKG} \mathrm{C}^{+}$subset was significantly increased, compared to non-self $\mathrm{KIR}^{+} \mathrm{NK}$ cells, in patients with CMV reactivation after haplo-HSCT (day 60, 15.76 \pm 1.22 vs $7.13 \pm 1.07, P=0.037$; day $90,18.76 \pm 1.15$ vs $9.64 \pm 1.51, P=0.041$; day $120,22.37 \pm 2.42$ vs $11.06 \pm$ $1.68, P=0.032$; day $150,23.41 \pm 3.03$ vs $7.74 \pm 1.23, P=$

B

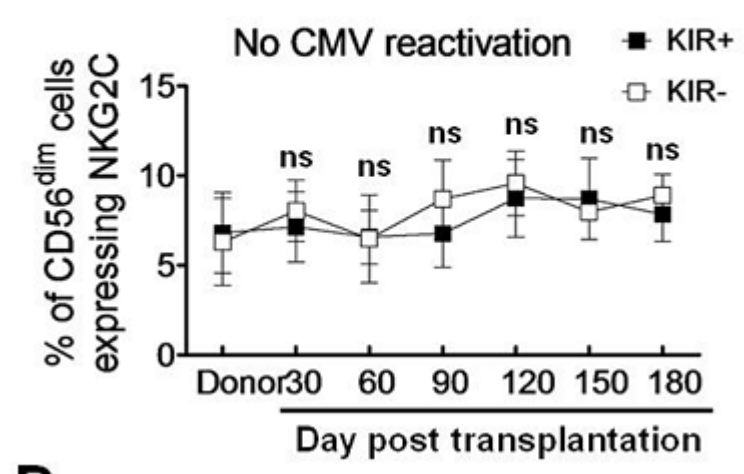

D

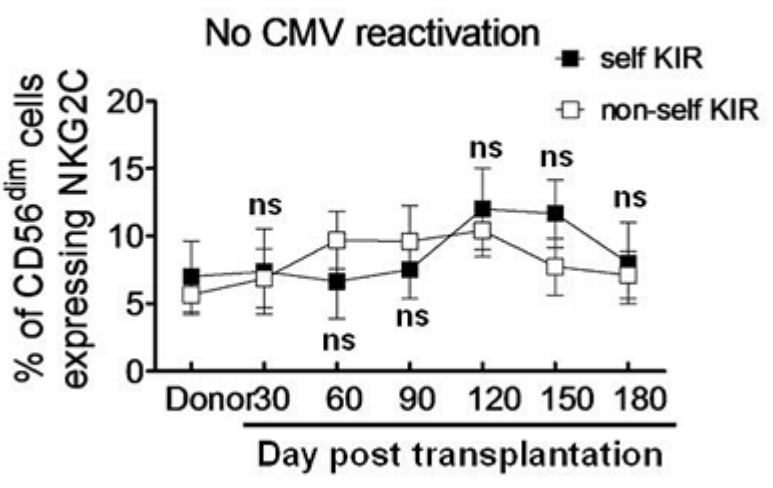

Figure 3: Self-KIR is expressed on expanding $\mathrm{NKG}^{+} \mathrm{C}^{+} \mathrm{NK}$ cells during CMV reactivation post haplo-HSCT. A.-B. KIR and $\mathrm{KIR}^{-} \mathrm{NK}$ cells were distinguished by flow cytometry using antibodies specifically against KIR2DL1, KIR3DL1 and KIR2DL3. The percentage of the $\mathrm{CD} 56^{\mathrm{dim}} \mathrm{NKG} 2 \mathrm{C}^{+} \mathrm{NK}$ cells were determined in the $\mathrm{KIR}^{+}(\boldsymbol{\bullet})$ and $\mathrm{KIR}^{-}(\square)$ populations respectively in patients with $(\mathbf{A}$., $n$ $=19$ ) or without CMV reactivation (B., $n=10$ ). Values represent mean $\pm \mathrm{SEM}$. ${ }^{*} P<0.05$ and ns (not significant) $P>0.05$ for comparisons between the $\mathrm{KIR}^{+}$and $\mathrm{KIR}^{-}$groups. C.-D. Self-KIR and non-self-KIR were determined based on the patient KIR ligand status. The percentage of the CD56 ${ }^{\mathrm{dim}} \mathrm{NKG} 2 \mathrm{C}^{+} \mathrm{NK}$ cells were assessed by flow cytometry in the self-KIR ( $\left.\mathbf{\square}\right)$ and non-self-KIR( $\square$ ) patients with (C., $n=10$ for self-KIR and $n=9$ for non-self-KIR) or without CMV reactivation (D., $n=5$ for self-KIR and non-self-KIR each), respectively. Values represent mean \pm SEM. $* P<0.05$ and ns (not significant) $P>0.05$ for comparisons between the self-KIR and non-self-KIR groups. 
0.015 ; day $180,27.82 \pm 2.46$ vs $13.87 \pm 1.34, P=0.025$; Figure 3C). Again, there was no significant difference between self-KIR ${ }^{+}$and non-self $\mathrm{KIR}^{+} \mathrm{NK}$ cells in patients without $\mathrm{CMV}$ reactivation $(P>0.05$ for each time point; Figure 3D). These findings indicate that the expanded CD56 ${ }^{\text {dim }} \mathrm{NKG} 2 \mathrm{C}^{+} \mathrm{NK}$ cells preferentially express KIR, especially self-KIR, in response to CMV reactivation in patients after haplo-HSCT. It is noteworthy that expression of either NKG2C (Figure 2B) or KIR (Figure 2D), as well as both NKG2C and KIR (Figure 3A) or self-KIR (Figure $3 \mathrm{C}$ ), in the $\mathrm{CD}^{\mathrm{dim}}$ subset of NK cells persisted for at least 6 months, suggesting their memory-like features as observed after umbilical cord blood HSCT [10].

\section{$\mathrm{NKG}^{2} \mathrm{C}^{+} \mathrm{NK}$ cells are functional in post haplo- HSCT patients with CMV reactivation}

In a well-characterized murine model of CMV infection, memory-like NK cells expressing the activating receptor $\mathrm{Ly} 49 \mathrm{H}$ recognize the viral protein $\mathrm{m} 157$ and expand after the initial viral infection [5]. Of note, similar memory NK-cell response has been demonstrated in human CMV infection [11]. As $\mathrm{NKG}_{2} \mathrm{C}^{+} \mathrm{NK}$ cells expanded and preferentially expressed KIR during CMV reactivation (Figure $3 \mathrm{~A}$ ), we then examined whether the expanded $\mathrm{NKG}_{2} \mathrm{C}^{+} \mathrm{NK}$ cells were functional by measuring IFN $\gamma$ production and CD107a expression as negative control in response to the HLA class I-negative K562 cells [10]. After incubation with K562 cells for 5 hrs, the percentage of IFN $\gamma$-producing $\mathrm{NKG}_{2} \mathrm{C}^{+} \mathrm{NK}$ cells was significantly greater than that for $\mathrm{NKG}_{2} \mathrm{C}^{-} \mathrm{NK}$ cells in patients with CMV reactivation after haplo-HSCT (day $30,4.63 \pm 0.57$ vs $2.32 \pm 0.56, P=0.072$; day $60,8.56$ \pm 2.06 vs $4.23 \pm 0.87, P=0.036$; day $90,9.46 \pm 1.67 v s$ $5.15 \pm 0.72, P=0.040$; day $120,9.57 \pm 1.14$ vs $4.42 \pm$ $0.73, P=0.028$; day $150,10.31 \pm 1.19$ vs $4.43 \pm 0.49, P$ $=0.023$; day $180,9.61 \pm 0.45$ vs $4.72 \pm 0.52, P=0.035$; Figure 4A). However, there was no significant difference in the percentage of IFN $\gamma$-producing $\mathrm{NK}$ cells between the $\mathrm{NKG}_{2} \mathrm{C}^{+}$and $\mathrm{NKG}_{2} \mathrm{C}^{-}$subsets in patients without CMV reactivation $(P>0.05$ for each time point; Figure

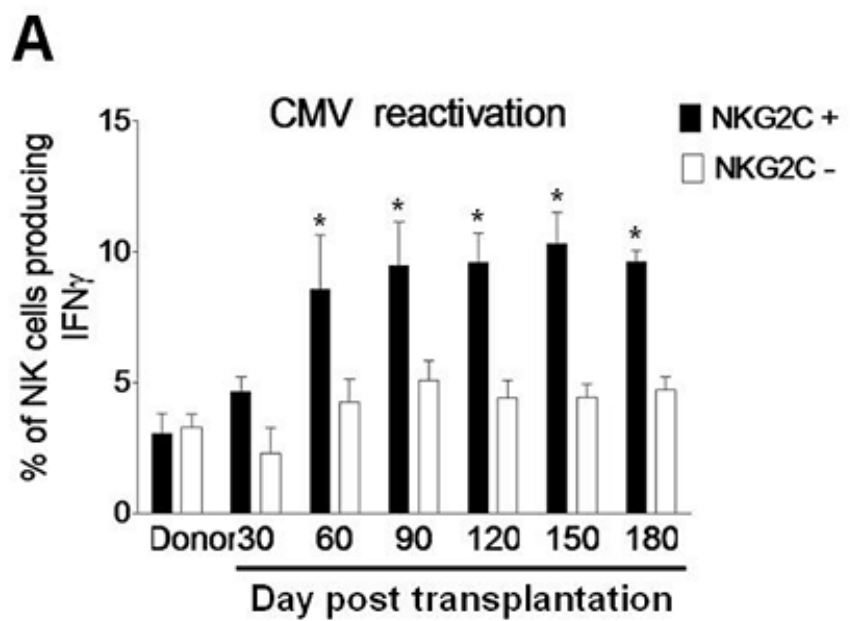

B
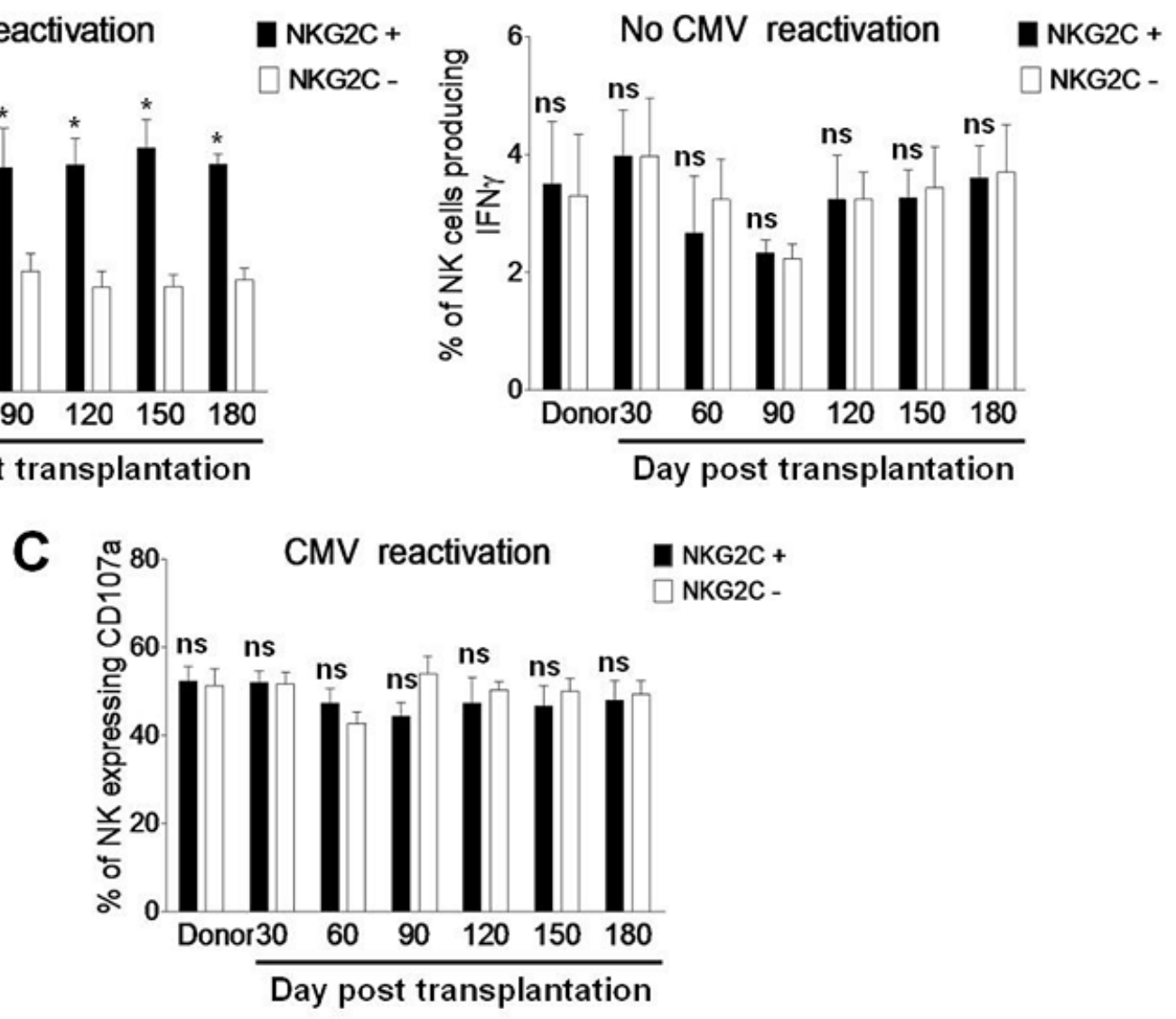

Figure 4: NKG2C is expressed in IFN $\gamma$-producing NK cells during CMV reactivation post haplo-HSCT. A. PBMCs from the donors $(n=8)$ and haplo-HSCT patients with CMV reactivation $(n=19)$ and $\mathbf{B}$. from the donors $(n=6)$ and haplo-HSCT patients without CMV reactivation $(n=10)$ were collected at days $30,60,90,120,150$, and 180 after transplantation. Cells were then incubated with K562 cells for $5 \mathrm{hrs}$, after which the percentages of IFN $\gamma$-producing NK cells were determined by flow cytometry in the NKG2C ${ }^{+}(\mathbf{\square})$ or $\mathrm{NKG}_{2} \mathrm{C}^{-}(\square)$ subset, respectively. C. In parallel, CD107a expression was measured by flow cytometry as positive control. Values represent mean \pm SEM. ${ }^{*} P<0.05$ and ns (not significant) $P>0.05$ for comparisons between the $\mathrm{NKG}^{+} \mathrm{C}^{+}$and $\mathrm{NKG}^{-} \mathrm{C}^{-}$groups. 
4B). Moreover, there was also no significant difference in the percentage of NK cells expressing CD107a between the $\mathrm{NKG}_{2} \mathrm{C}^{+}$and $\mathrm{NKG}_{2} \mathrm{C}^{-}$subsets in patients with $\mathrm{CMV}$ reactivation $(P>0.05$ for each time point; Figure $4 C)$. These findings suggest that $\mathrm{NKG}_{2} \mathrm{C}^{+} \mathrm{NK}$ cells in haploHSCT patients with CMV reactivation are functional for long-term to produce IFN $\gamma$.

\section{Self-KIR expression on NK cells of post haplo- HSCT patients with CMV reactivation is required for IFN $\gamma$ production}

The functions of NK cells reconstituted after transplantation include cytokine production and degranulation. Whereas degranulation is similar between the $\mathrm{KIR}^{+}$and $\mathrm{KIR}^{-}$populations, target cell-induced IFN $\gamma$ production is restricted only to the subset of $\mathrm{KIR}^{+} \mathrm{NK}$ cells [22]. In this context, we last examined whether the expanded self-KIR ${ }^{+} \mathrm{NK}$ cells are functional by measuring
IFN $\gamma$ production and CD107a expression in response to K562 cells as described above. After exposure to K562 cells for $5 \mathrm{hrs}$, the percentage of IFN $\gamma$-producing NK cells was significantly increased in the subset of self-KIR ${ }^{+} \mathrm{NK}$ cells, but not non-self $\mathrm{KIR}^{+} \mathrm{NK}$ cells, in patients with CMV reactivation after haplo-HSCT (day 30, $4.73 \pm 0.68$ vs $3.22 \pm 0.36, P=0.046$; day $60,4.63 \pm 0.61$ vs $1.63 \pm$ $0.318, P=0.022$; day $90,5.32 \pm 0.73$ vs $2.62 \pm 0.26, P=$ 0.028 ; day $120,4.43 \pm 0.93$ vs $1.93 \pm 0.37, P=0.039$; day $150,4.93 \pm 0.76$ vs $2.32 \pm 0.46, P=0.032$; day $180,5.56$ \pm 0.43 vs $1.66 \pm 0.23, P=0.021$; Figure 5A). However, between the self-KIR ${ }^{+}$and non-self $\mathrm{KIR}^{+}$subsets, there was no significant difference in the percentage of IFN $\gamma$ producing NK cells in patients without CMV reactivation (Figure 5B, $P>0.05$ for each time point) or CD107aexpressing NK cells as negative control in patients with CMV reactivation (Figure $5 \mathrm{C}, P>0.05$ for each time point). These findings suggest that self-KIR ${ }^{+} \mathrm{NK}$ cells in patients with CMV infection after haplo-HSCT are functional for long term to produce IFN $\gamma$.

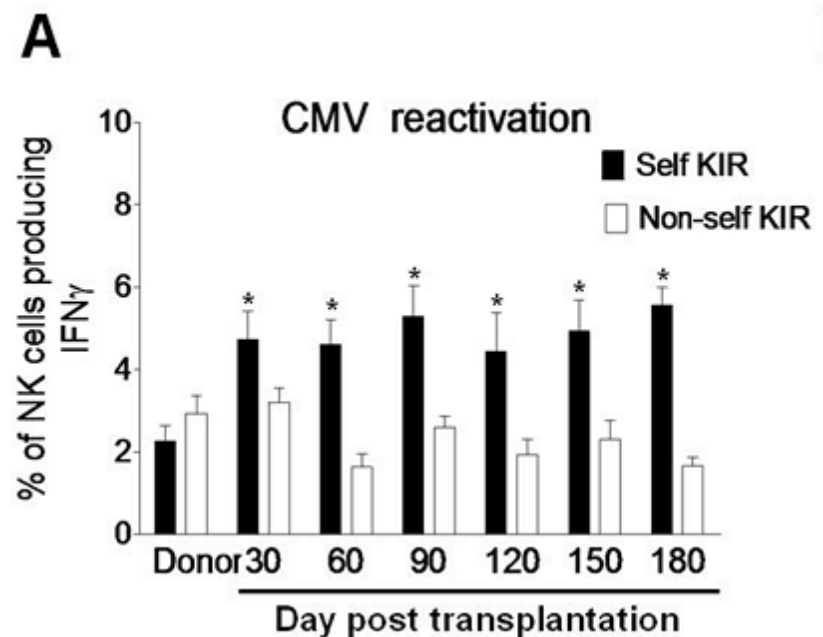

B

Day post transplantation
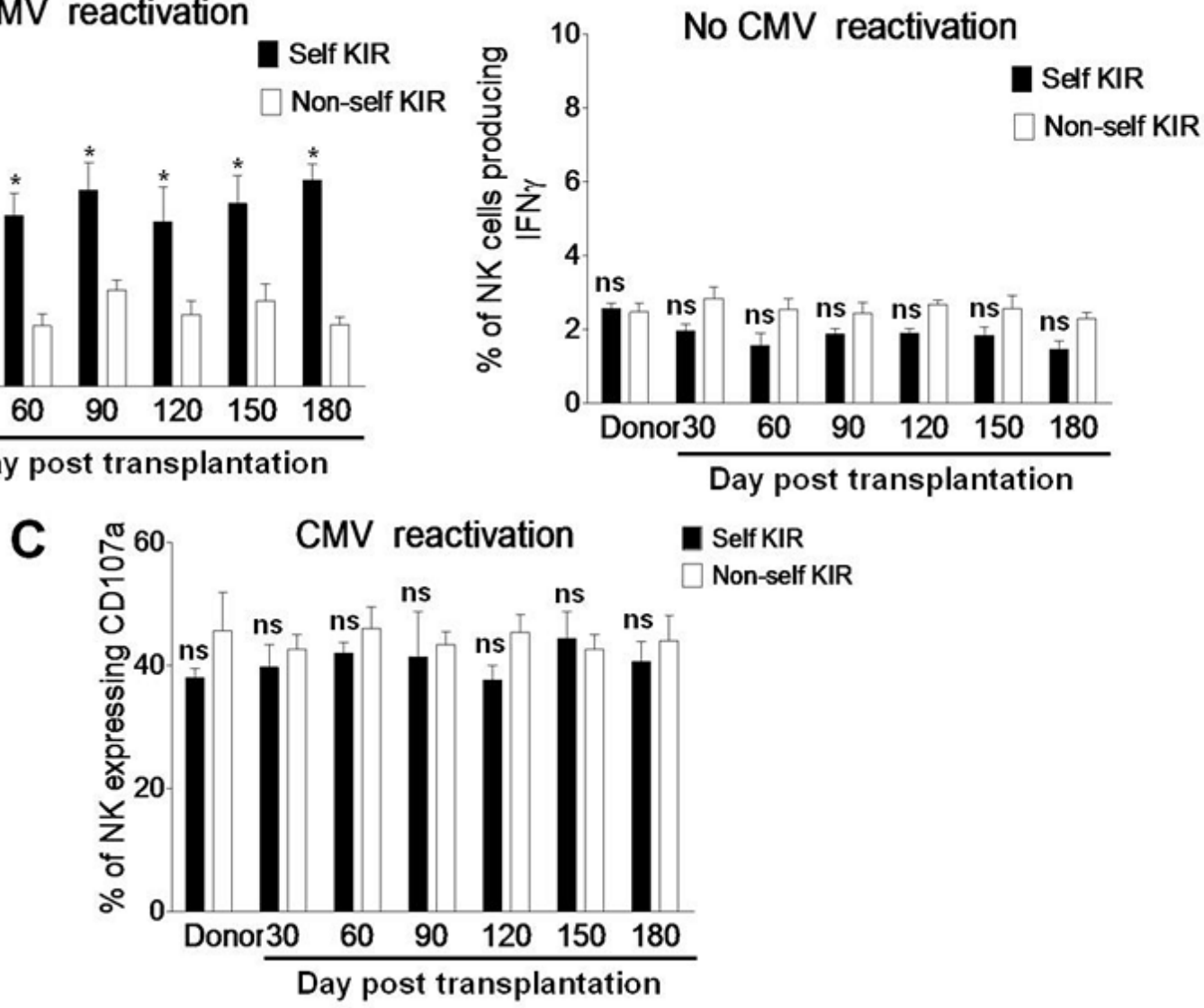

Figure 5: Self-KIR is expressed in IFN $\gamma$-producing NK cells during CMV reactivation post haplo-HSCT. A. PBMCs from the donors $(n=8)$ and haplo-HSCT patients with CMV reactivation $(n=19)$ and $\mathbf{B}$. from the donors $(n=6)$ and haplo-HSCT patients without CMV reactivation $(n=10)$ were collected at days 30,60,90,120,150, and 180 after transplantation. Cells were then incubated with K562 cells for $5 \mathrm{hrs}$, after which the percentages of IFN $\gamma$-producing NK cells were determined by flow cytometry in the self-KIR ( $\mathbf{}$ ) or non-self KIR ( $\square$ ) subset. C. In parallel, CD107a expression was measured by flow cytometry as positive control. Values represent mean \pm SEM. ${ }^{*} P<0.05$ and ns (not significant) $P>0.05$ for comparisons between the self-KIR and non-self-KIR groups. 


\section{DISCUSSION}

In the present study, we demonstrated that IFN $\gamma$ producing NK cells expanded in response to CMV infection in patients and persisted for at least 6 months after haplo-HSCT, suggesting their memory-like feature. Further, CMV reactivation induced a more mature phenotype of NK cells characterized by CD56 dim and preferential expression of $\mathrm{NKG} 2 \mathrm{C}$ and self-KIR after transplantation, which are responsible for IFN $\gamma$ production. Last, NK cells expressing NKG2C and selfKIR in haplo-HSCT patients with CMV reactivation are functional for long term to produce IFN $\gamma$ in response to K562 cells. Allogeneic HSCT, which subsequently induces a potent graft versus leukemia effect, is a potentially curative therapy for hematologic malignancies. While MRD or MUD could not be identified as an ideal donor for a majority of patients, haplo-HSCT with high donor availability appears to offer an immediate treatment option. This approach is also less time-consuming than conventional HSCT that requires a stringent matching process. However, although haplo-HSCT could reduce leukemia relapse, it is also often associated with serious immunosuppression due to treatment of severe GVHD caused by HLA-mismatch and thus increases risk of infection, particularly with CMV. High morbidity and mortality of CMV infection as well as delayed immune reconstitution post transplantation remain to be the critical obstacles for success of haplo-HSCT. However, our study demonstrated that CMV reactivation induces the expansion of cytotoxic NK cells with memory-like features, which might in turn contribute to control of viral infection, as well as probably prevention of leukemia relapse as well, in patients after haplo-HSCT.

It has been reported that there is no statistically difference in counts of total and CD56 $6^{\mathrm{dim}} \mathrm{NK}$ cells between patients with malignant or non-malignant diseases within six months after transplanted with either bone marrow or peripheral blood stem cells, and between patients conditioned with either myeloablative and reduced intensity conditioning [27]. However, total and CD56 ${ }^{\text {dim }}$ NK cells are significantly lower in patients who had grades 2-4 acute GVHD than those with grades 0-1 acute GVHD, indicating acute GVHD as an important determinant that influences counts of total as well as CD56 $6^{\mathrm{dim}} \mathrm{NK}$ cells. Therefore, we selected a cohort of patients with 0-1 acute GVHD after haplo-HSCT in this study, in order to avoid the potential effects of acute GVHD on the readouts of our analyses on total and particularly CD56 $6^{\mathrm{dim}} \mathrm{NK}$ cells.

In concordance to the previous observation after umbilical cord blood (UCB) and 1 HLA-matched sibling transplantation [10], we observed that $\mathrm{CMV}$ reactivation induced expansion of the $\mathrm{NKG}_{2} \mathrm{C}^{+}$memory-like NK cells in patients after haplo-HSCT, which in turn produced IFN $\gamma$ to control of CMV infection. NK cells are the first cell population to reconstitute following HSCT. It has been found that similar to $\mathrm{Ly} 49 \mathrm{H}^{+} \mathrm{NK}$ cells in mice, NK cells expressing the activating $\mathrm{C}$-type lectin-like receptor NKG2C might represent memory-like NK cells in humans $[11,28]$. NKG2C recognizes the non-classical class I allele HLA-E, while its inhibitory counterpart NKG2A also recognizes HLA-E [29]. Although CMV infection results in a down-regulation of the class I HLA, HLA-E often remains intact on the cell surface [30,31]. Whereas $\mathrm{NKG}_{2} \mathrm{C}^{+} \mathrm{NK}$ cells expand in co-culture with cell lines transfected with HLA-E and IL-15 [32], CMV-infected cells might express HLA-E loaded with a viral peptide that drives NKG2C expansion, or alternatively, encode a viral protein that binds to NKG2C [11]. Moreover, it has been demonstrated that the CD94/NKG2C/HLA-E axis represents an important mechanism for the expansion of $\mathrm{NKG} 2 \mathrm{C}^{+} \mathrm{NK}$ cells in response to human CMV infection [8]. It has been reported that several toll-like receptors (e.g., TLR2, 3, 9, and recently TLR 5) are involved in NK cell-mediated control of CMV in mice [33, 34]. However, the intracellular signals and molecular mechanism responsible for $\mathrm{CMV}$-induced expansion of $\mathrm{NKG}_{2} \mathrm{C}^{+} \mathrm{NK}$ cells remains virtually unknown in human, especially after HSCT.

The bulk of evidence have demonstrated the relationship between KIR and CMV reactivation. For example, the activating receptor $\mathrm{Ly} 49 \mathrm{H}$ in mice, analogous to KIRs in humans, are mainly engaged in control of murine CMV infection [21]. Whereas KIRs are expressed on NK cells during CMV reactivation [10, 11], KIR expression is required for educating NK cells to produce IFN $\gamma$ after allogeneic HSCT [22]. In the present study, we found that NK cells expressing KIR that recognizes self-HLA, expanded and produced IFN $\gamma$ in haplo-HSCT patients with CMV reactivation. This result is similar to the previous observations that self-KIR, especially CD158b (e.g., KIR2DL2, KIR2DL3, and KIR2DS2), is predominately expressed on IFN $\gamma$-producing NK cells in patients after umbilical cord blood, MRD, or MUD HSCT $[10,11,22]$. We further found that self-KIR was preferentially expressed on expanded $\mathrm{NKG}_{2} \mathrm{C}^{+} \mathrm{NK}$ cells in the present setting, consistent with the earlier observation that $\mathrm{CMV}$ drives expansion of $\mathrm{NKG} \mathrm{C}^{+}$cells expressing self-specific KIRs in chronic hepatitis patients [35]. In turn, KIR expression on NK cells is critical for robust IFN $\gamma$ production, a potential mechanism underlying both control of viral infection and suppression of tumor growth after HSCT [10, 11, 36-38]. Regarding the ligands of KIR, it has been reported that a hierarchical effect on NK cell function primarily depends on different HLA-C1 alleles, but there is no difference between HLA-C2 alleles [39]. Interestingly, donors who are homozygous for HLA-C*07 (HLA-C1) are potent IFN $\gamma$ producers, while those who are homozygous for HLA-C*1402 are, however, very poor IFN $\gamma$ producers. On the other hand, expression of the inhibitory KIR specific for self-HLA class I ligand is also essential for alloreactivity of NK cells 
between donor and recipient [40]. The inhibitory KIR in recipients could sense the missing expression of donor KIR ligands and thereby trigger alloreactions. In this context, KIR2DL1, KIR2DL2/KIR2DL3, and KIR3DL1 recognize the HLA-C2, HLA-C1, and HLA-Bw4 alleles, respectively. Mismatch of these three KIR ligands (in the GvH direction) can lead to donor versus recipient NK cell alloreactivity. However, it remains to be defined whether CMV-induced KIR expression might also contribute to alloreactivity of NK cells after HSCT.

In summary, our study revealed expansion of IFN $\gamma$ producing NK cells in patients with CMV infection after haplo-HSCT and characterized these expanded cells as a CD56 ${ }^{\text {dim }}$ subset of NK cells with a more mature phenotype preferentially expressing NKG2C and self-KIR. These results suggest that $\mathrm{CMV}$ reactivation might shape the NK cell receptor repertoires. Moreover, NK cells expressing NKG2C and self-KIR during CMV reactivation are functionally responsible for robust IFN $\gamma$ production as well as display memory-like features. Thus, this study provide evidence supporting a notion that NK cells characterized by CD56 ${ }^{\mathrm{dim}}, \mathrm{NKG}_{2} \mathrm{C}^{+}$and self-KIR ${ }^{+}$expand and persist in response to $\mathrm{CMV}$ reactivation in patients after haplo-HSCT, which in turn produce IFN $\gamma$ to control CMV infection as well as prevent leukemia relapse. Of note, the similarity in the observations between haploHSCT in the present study and UCB or MRD HSCT [10] argues strongly that such a NK cell response might solely stem from CMV infection, while independent of HSCT donor types. Therefore, the molecular mechanism(s) by which CMV induces the selective expansion of functional and memory-like NK cells warrants further investigation in patients after HSCT.

\section{MATERIALS AND METHODS}

\section{Patients}

Patient samples were obtained with the approval of Institutional Review Boards and the informed consent from each patient. A total of 29 haplo-HSCT patients were enrolled into this study in the General Hospital of the Air Force of the Chinese People's Liberation Army and the First Bethune Hospital of Jilin University between August 2011 and November 2014. Among them, there were 19 patients with CMV infection and 10 patients without CMV infection. All patients had received myeloablative conditioning with cytarabine $\left(4 \mathrm{~g} / \mathrm{m}^{2}\right.$ per day, days -10 to -9$)$, busulfan $(3.2 \mathrm{mg} / \mathrm{kg}$ per day, intravenously days -8 to -6$)$, cyclophosphamide $\left(1.8 \mathrm{~g} / \mathrm{m}^{2}\right.$ per day, days -5 to -4$)$, semustine $\left(250 \mathrm{mg} / \mathrm{m}^{2}\right.$, day -3$)$, and rabbit ATG (thymoglobulin, $2.5 \mathrm{mg} / \mathrm{kg}$ per day, days -5 to -2 ) [41]. All patients were infused with granulocyte colony stimulating factor (G-CSF)-mobilized peripheral blood stem cells
(PBSCs) and bone marrow grafts from haploidentical donors (days +1 to +2 ). GVHD prophylaxis included cyclosporine A, methotrexate, and mycophenolate mofetil. There was no difference in GVHD prophylaxis between patients with or without CMV reactivation. Patients were monitored weekly for CMV reactivation by quantitative PCR (qPCR) performed in the Clinical Virology Laboratory. CMV viremia ( $>100$ copies) was treated with ganciclovir until CMV viremia became negative $(<100$ copies) [11]. Peripheral blood mononuclear cells (PBMCs) from pre-HSCT samples of all donors and post-HSCT samples of recipients at 3 and 6 month after transplantation were collected. After haplo-HSCT, 19 patients developed detectable HCMV reactivation in the blood during 19 69 days after transplantation. High resolution HLA typing was performed, by which NK ligand status was assigned on the basis of Bw4, HLA-C1, HLA-C2, and HLA-A03/11 group ligands.

\section{Antibodies and flow cytometry}

The NK cell surface phenotype was determined by flow cytometry (FACSCalibur, BD Biosciences) using the monoclonal antibodies (mAbs) as follows: CD3PerCP (SK7; BD Biosciences), CD56-allophycocyanin (B159; BD Biosciences), NKG2C-PE (134591; R\&D Systems), NKG2A (Z199; Beckman Coulter), NKG2D (ID11; BD Biosciences), KIR2DL1-FITC (143211; R\&D Systems), KIR3DL1 (DX9, Miltenyi), KIR3DL2-biotin (streptavidin-Qdot.605), KIR2DL2/2DL3/2DS2-PE (GL183; Beckman Coulter), KIR2DL2/S2/L3 (DX27, Miltenyi), and isotypematched controls (IgG1 from BD Pharmingen, IgG2a from R\&D Systems). Dead cells were excluded by propidium iodine (PI) staining, while PInegative live cells were gated in for analysis. Non-reactive allophycocyanin-labeled rat $\operatorname{IgG} 2 \mathrm{a}$ mAbs were used as negative controls.

Intracellular production of IFN $\gamma$ and expression of CD107a was measured using Pacific blue-conjugated anti-IFN $\gamma$ (clone 4S.B3; BioLegend) and anti-CD107a (H4A3; BD Biosciences) as reported previously [10]. Briefly, PBMCs were isolated from each sample by density-gradient centrifugation and cryopreserved. Before analysis, cells were thawed and assessed after incubation with $\mathrm{K} 562$ cells for $5 \mathrm{~h}$ at $37^{\circ} \mathrm{C}$ in complete DMEM (without exogenous cytokines) supplemented with $20 \%$ human AB serum (Valley Biomedical), 30\% Ham F-12 medium (Cellgro), $100 \mathrm{U} / \mathrm{mL}$ of penicillin (Invitrogen), $100 \mathrm{U} / \mathrm{mL}$ of streptomycin (Invitrogen), $24 \mu \mathrm{M}$ 2- $\beta$-mercaptoethanol, $50 \mu \mathrm{M}$ ethanolamine, $20 \mathrm{mg} / \mathrm{L}$ of ascorbic acid, and $50 \mu \mathrm{g} / \mathrm{L}$ of sodium selenate. The human erythroleukemia cell line K562 was maintained in IMDM supplemented with $10 \% \mathrm{FBS}, 100 \mathrm{U} / \mathrm{mL}$ of streptomycin, and $100 \mathrm{U} / \mathrm{mL}$ of penicillin. Data were analyzed using FlowJo 7.6.1 software (Tree Star) [12]. 


\section{HLA and KIR typing}

Complete high-resolution, allele-level typing data for HLA-A, HLA-B, HLA-C, HLA-DRB1 and HLADQB1 were obtained from the High-resolution HLA Typing Laboratory in the China Marrow Donor Program. KIR genes were typed using the PCR-SSP methods as per the manufacturers' instruction, as described previously $[36,42]$.

\section{Statistical analysis}

Data are presented as mean and SE (mean \pm SEM). Differences between groups were analyzed using the Student's t test. Paired $t$ test was used for comparisons of matched samples. All statistical analyses were performed using SAS version 9.2 (SAS Institute, Cary, NC). P value $<0.05$ was considered to be significant.

\section{ACKNOWLEDGMENTS}

We thank Professors Yongguang Yang and Liguang Sun for their technical support.

\section{CONFLICTS OF INTEREST}

All authors declare no conflicts of interest.

\section{GRANT SUPPORT}

This work was supported by the Norman Bethune Program of Jilin University (2012224), the National Natural Science Foundation of China (81100350, 81471165, and 81670190), the Fundamental Research Fund of the Jilin University (450060445226), and the Science Foundation for the 49th Chinese Postdoc Grant (20110490155), Jilin Province health family planning research plan (grant \# 20142041) and Jilin Province young Science Foundation of technology development plan (grant \# 201201019).

\section{REFERENCES}

1. Saber W, Opie S, Rizzo JD, Zhang M-J, Horowitz MM and Schriber J. Outcomes after matched unrelated donor versus identical sibling hematopoietic cell transplantation in adults with acute myelogenous leukemia. Blood. 2012; 119:39083916.

2. Parmesar K and Raj K. Haploidentical stem cell transplantation in adult haematological malignancies. Adv Hematol. 2016; 2016:3905907.

3. Moretta A, Bottino C, Vitale M, Pende D, Biassoni R, Mingari MC and Moretta L. Receptors for HLA class-I molecules in human natural killer cells. Annu Rev
Immunol. 1996; 14:619-648.

4. Moretta A, Bottino C, Vitale M, Pende D, Cantoni C, Mingari $\mathrm{MC}$, Biassoni $\mathrm{R}$ and Moretta L. Activating receptors and coreceptors involved in human natural killer cell-mediated cytolysis. Annu Rev Immunol. 2001; 19:197223.

5. Lanier LL. Evolutionary struggles between NK cells and viruses. Nat Rev Immunol. 2008; 8: 259-268.

6. Vivier E, Tomasello E, Baratin M, Walzer T and Ugolini S. Functions of natural killer cells. Nat Immunol. 2008; 9:503510.

7. Long EO. Signal sequences stop killer cells. Nature. 1998; 391:740-743.

8. Rölle A,1 Pollmann J, Ewen E-M, Le VTK, Halenius A, Hengel $\mathrm{H}$ and Cerwenka A. IL-12-producing monocytes and HLA-E control HCMV-driven NKG2C+ NK cell expansion. J Clin Invest. 2014; 124:5305-5316.

9. Béziat V, Liu LL, Malmberg JA, Ivarsson MA, Sohlberg E, Björklund AT, Retière C, Sverremark-Ekström E, Traherne J, Ljungman P, Schaffer M, Price DA, Trowsdale J, et al. NK cell responses to cytomegalovirus infection lead to stable imprints in the human KIR repertoire and involve activating KIRs. Blood. 2013; 121:2678-2688.

10. Foley B, Cooley S, Verneris MR, Pitt M, Curtsinger J, Luo X, Lopez-Vergès S, Lanier LL, Weisdorf $\mathrm{D}$ and Miller JS. Cytomegalovirus reactivation after allogeneic transplantation promotes a lasting increase in educated $\mathrm{NKG} 2 \mathrm{C}+$ natural killer cells with potent function. Blood. 2012; 119:2665-2674.

11. Foley B, Cooley S, Verneris MR, Curtsinger J, Luo X, Waller EK, Anasetti C, Weisdorf D and Miller JS. Human cytomegalovirus (CMV)-induced memory-like NKG2C(+) NK cells are transplantable and expand in vivo in response to recipient CMV antigen. J Immunol. 2012; 189:50825088 .

12. Charoudeh HN, Terszowski G, Czaja K, Gonzalez A, Schmitter K and Stern M. Modulation of the natural killer cell KIR repertoire by cytomegalovirus infection. Eur J Immunol. 2013; 43:480-487.

13. Monsiváis-Urenda A, Noyola-Cherpitel D, HernándezSalinas A, García-Sepúlveda C, Romo N, Baranda L, López-Botet $\mathrm{M}$ and González-Amaro R. Influence of human cytomegalovirus infection on the NK cell receptor repertoire in children. Eur J Immunol. 2010; 40:1418-1427.

14. Biron CA. Expansion, maintenance, and memory in NK and $\mathrm{T}$ cells during viral infections: responding to pressures for defense and regulation. PLoS Pathog. 2010; 6:e1000816.

15. Sun JC, Beilke JN and Lanier LL. Adaptive immune features of natural killer cells. Nature. 2009; 457:557-561.

16. Foley B, Cooley S, Verneris MR, Curtsinger J, Luo X, Waller EK, Weisdorf DJ and Miller JS. NK cell education after allogeneic transplantation: dissociation between recovery of cytokine-producing and cytotoxic functions. Blood. 2011; 118:2784-2792. 
17. Foley B, Felices M, Cichocki F, Cooley S, Verneris MR and Miller JS. The biology of NK cells and their receptors affects clinical outcomes after hematopoietic cell transplantation (HCT). Immunol Rev. 2014; 258:45-63.

18. Jacobs R, Hintzen G, Kemper A, Beul K, Kempf S, Behrens G, Sykora KW and Schmidt RE. CD56bright cells differ in their KIR repertoire and cytotoxic features from CD56dim NK cells. Eur J Immunol. 2001; 31:3121-3127.

19. Robertson MJ, Manley TJ, Donahue C, Levine H and Ritz J. Costimulatory signals are required for optimal proliferation of human natural killer cells. J Immunol. 1993; 150:17051714.

20. Malhotra1 A and Shanker A. NK cells: immune crosstalk and therapeutic implications. Immunotherapy. 2011; 3:1143-1166.

21. Babić M, Krmpotić A and Jonjić S. All is fair in virus-host interactions: NK cells and cytomegalovirus.Trends Mol Med. 2011; 17:677-685.

22. Foley B, Cooley S, Verneris MR, Curtsinger J, Luo X, Waller EK, Weisdorf DJ and Miller JS. NK cell education after allogeneic transplantation: dissociation between recovery of cytokine-producing and cytotoxic functions. Blood. 2011; 118:2784-2792.

23. Boyington JC and Sun PD. A structural perspective on MHC class I recognition by killer cell immunoglobulin-like receptors. Mol Immunol. 2002; 38:1007-1021.

24. Cooley S, Weisdorf DJ, Guethlein LA, Klein JP, Wang T, Marsh SG, Spellman S, Haagenson MD, Saeturn K, Ladner M, Trachtenberg E, Parham P and Miller JS. Donor killer cell Ig-like receptor B haplotypes, recipient HLA-C1, and HLA-C mismatch enhance the clinical benefit of unrelated transplantation for acute myelogenous leukemia. J Immunol. 2014; 19:4592-600.

25. Gumperz JE, Litwin V, Phillips JH, Lanier LL and Parham P. The Bw4 public epitope of HLA-B molecules confers reactivity with natural killer cell clones that express NKB1, a putative HLA receptor. J Exp Med. 1995; 181:1133-44.

26. Gumperz JE, Barber LD, Valiante NM, Percival L, Phillips JH, Lanier LL and Parham P. Conserved and variable residues within the Bw4 motif of HLA-B make separable contributions to recognition by the NKB1 killer cellinhibitory receptor. J Immunol. 1997; 158:5237-5241.

27. Kheav VD, Busson M, Scieux C, Peffault de Latour R, Maki G, Haas P, Mazeron MC, Carmagnat M, Masson E, Xhaard A, Robin M, Ribaud P, Dulphy N, et al. Favorable impact of natural killer cell reconstitution on chronic graft-versus-host disease and cytomegalovirus reactivation after allogeneic hematopoietic stem cell transplantation. Haematologica. 2014; 99:1860-1867.

28.Sun JC, Beilke JN and Lanier LL. Adaptive immune features of natural killer cells. Nature. 2009; 457:557-561.

29.Braud VM, Allan DS, O’Callaghan CA, Söderström K, D’Andrea A, Ogg GS, Lazetic S, Young NT, Bell JI, Phillips JH, Lanier LL and McMichael AJ. HLA-E binds to natural killer cell receptors CD94/NKG2A, B and C. Nature. 1998; 391:795-799.

30. Tomasec P, Braud VM, Rickards C, Powell MB, McSharry BP, Gadola S, Cerundolo V, Borysiewicz LK, McMichael AJ and Wilkinson GW. Surface expression of HLA-E, an inhibitor of natural killer cells, enhanced by human cytomegalovirus gpUL40. Science. 2000; 287:1031.

31. Llano M, Gumá M, Ortega M, Angulo A and López-Botet M. Differential effects of US2, US6 and US11 human cytomegalovirus proteins on HLA class Ia and HLA-E expression: impact on target susceptibility to NK cell subsets. Eur J Immunol. 2003; 33:2744-2754.

32. Björkström NK, Lindgren T, Stoltz M, Fauriat C, Braun M, Evander M, Michaëlsson J, Malmberg KJ, Klingström J, Ahlm C and Ljunggren HG. Rapid expansion and long-term persistence of elevated NK cell numbers in humans infected with hantavirus. J Exp Med. 2011; 208:13-21.

33. Szomolanyi-Tsuda E, Liang X, Welsh RM, Kurt-Jones EA and Finberg RW. Role for TLR2 in NK cell-mediated control of murine cytomegalovirus in vivo. J Virol 2006; 80: 4286-4291.

34. Hossain MS, Ramachandiran S, Gewirtz AT and Waller EK. Recombinant TLR5 agonist CBLB502 promotes NK cellmediated anti-CMV immunity in mice. PLOS ONE 2014; 9:e96165.

35. Be'ziat V, Dalgard O, Asselah T, Halfon P, Bedossa P, Boudifa A, Hervier B, Theodorou I, Martinot M, Debre' P, Bjo“rkstro“m NK, Malmberg K-J, Marcellin P, et al. CMV drives clonal expansion of NKG2C1 NK cells expressing self-specific KIRs in chronic hepatitis patients. Eur J Immunol. 2012; 42:447-457.

36. Djaoud Z, David G, Bressollette C, Willem C, Rettman P, Gagne K, Legrand N, Mehlal S, Cesbron A, ImbertMarcille $\mathrm{BM}$ and Retière $\mathrm{C}$. Amplified $\mathrm{NKG} 2 \mathrm{C}+\mathrm{NK}$ cells in cytomegalovirus (CMV) infection preferentially express killer cell Ig-like receptor 2DL: functional impact in controlling CMV-infected dendritic cells. J Immunol. 2013; 191:2708-2716.

37. Shankaran V, Ikeda H, Bruce AT, White JM, Swanson PE, Old LJ and Schreiber RD. IFNgamma and lymphocytes prevent primary tumour development and shape tumour immunogenicity. Nature. 2001; 410:1107-1111.

38. Biron CA, Nguyen KB, Pien GC, Cousens LP and SalazarMather TP. Natural killer cells in antiviral defense: function and regulation by innate cytokines. Annu Rev Immunol. 1999; 17:189-220.

39. Yawata M, Yawata N, Draghi M, Partheniou F, Little AM and Parham P. MHC class I-specific inhibitory receptors and their ligands structure diverse human NK-cell repertoires toward a balance of missing self-response. Blood. 2008; 112:2369-2380.

40. Stern M, de Angelis C, Urbani E, Mancusi A, Aversa F, Velardi A and Ruggeri L. Natural killer-cell KIR repertoire reconstitution after haploidentical SCT. Bone Marrow 
Transplant. 2010; 45:1607-1610.

41. Wang Y, Chang YJ, Xu LP, Liu KY, Liu DH, Zhang XH, Chen H, Han W, Chen YH, Wang FR, Wang JZ, Chen Y, Yan $\mathrm{CH}$, et al. Who is the best donor for a related HLA haplotype-mismatched transplant? Blood. 2014; 124:843850 .

42. Chen DF, Prasad VK, Broadwater G, Reinsmoen NL, DeOliveira A, Clark A, Sullivan KM, Chute JP, Horwitz ME, Gasparetto C, Long GD, Yang Y, Chao NJ, et al.Differential impact of inhibitory and activating Killer IgLike Receptors (KIR) on high-risk patients with myeloid and lymphoid malignancies undergoing reduced intensity transplantation from haploidentical related donors. Bone Marrow Transplant. 2012; 47:817-823. 